\title{
Comparative Study of Anthropometric Measurement and Body Composition between Elite Soccer and Basketball Players
}

\author{
Estudio Comparativo de las Medidas Antropométricas y Composición \\ Corporal entre Futbolistas de Elite y Jugadores de Básquetbol
}

\author{
Stevo Popovic*; Selçuk Akpinar**; Damjan Jaksic***; Radenko Matic ${ }^{* * *}$ \& Dusko Bjelica*
}

POPOVIC, S.; AKPINAR, S.; JAKSIC, D.; MATIC, R. \& BJELICA, D. Comparative study of anthropometric measurement and body composition between elite soccer and basketball players. Int. J. Morphol., 31(2):461-467, 2013.

SUMMARY: The purpose of this study was to describe anthropometric characteristics and body composition of elite soccer and basketball players as well as to make comparisons between them. Seventy-one males were enrolled in the study, divided into three groups: twenty-six soccer players, fourteen basketball players and thirty-one healthy sedentary subjects. All subjects were assessed for the anthropometric measures required for the calculation of body composition variables, using the standardized procedures recommended by established literature. Data was analyzed using SPSS and the descriptive statistics were expressed as a mean (SD) for each variable, while the ANOVA and LSD Post Hoc tests were carried out to detect the effects of each type of sport. The results showed there was no significant difference in body mass index among the groups, while a significant difference was found for body height and body weight as well as for all three of the body contents measured (muscle, bone and fat) among the groups. Basketball players were significantly taller and heavier than soccer players and the subjects of the control group, while there was also a significant difference between the weight of soccer players and the subjects of the control group, who were significantly heavier. The muscle and bone contents in the bodies of the subjects in the control group were significantly lower than that of all other subjects while there was no difference between soccer and basketball players. Lastly, the fat content in the body of the subjects in the control group was significantly higher than that of all of the other subjects, while there was no difference between soccer and basketball players. Therefore, these findings may give coaches from the region better working knowledge and suggest them to follow recent selection process methods and to be more careful during the recruitment.

KEY WORDS: Sport; Top-Level; Football; Basket; Male.

\section{INTRODUCTION}

It is well-known fact that there is a growing interest in improving the performance of athletes (cited in Popovic et al., 2012) as well as identifying talent, strengths and weaknesses, assigning player positions and helping in the design of optimal training programmes (cited in Hadzic et al., 2012) all over the world, including Western Balkan countries. However, in many places much more time is spent on increasing the physical fitness of athletes without taking into consideration the assessment of their body composition and their nutritional status (Triki et al., 2012). Contemporary sport science is designed to improve the performance of elite players and to discover talents as precisely as possible. However, this process is very demanding, as various athletic events require different body types to achieve maximum performance. Therefore, understanding the body composition of elite players, and then assigning corresponding competitive weights for the athletes, has been done for decades and is considered an essential part of the total management process (Wilmore, 1982). On the other hand, although children and adolescent sportsmen grow in a manner similar to non-sportsmen (Rexhepi \& Brestovci, 2010a), it is widely addressed in the scientific literature that adequate profiles are primarily important in various sports, mostly due to the reason that absolute size contributes a significant percentage of total variance associated with athletic success (Carvajal et al., 2012). Therefore, scientists all over the world are looking for a standard formula that can improve the performance of elite players and discover talents as efficiently as possible.

The anthropometrical characteristics and body compositions of athletes has been the subject of many

\footnotetext{
Faculty for Sport and Physical Education, University of Montenegro, Narodne omladine bb, 81400 Niksic, Montenegro.

** Physical Education and Sport Department, Nevsehir Üniversitesi, 2000 Evler Mah. Zübeyde Hanım Cad., 50300 Nevsehir, Turkey.

${ }^{* * * *}$ Faculty of Sport and Physical Education University of Novi Sad, Lovcenska 16, 21000 Novi Sad, Serbia.
} 
investigations as many researchers have hypothesized that practicing athletes might be expected to exhibit structural and functional characteristics that are specifically favorable for their specific sport (Singh et al., 2010). Since each sport has its own specific demands, every athlete should have specific anthropometrical characteristics and body composition figures for his or her own sports discipline. Some sports, such as martial arts, require much more knowledge regarding this topic than others, because of its weight limits. However, this fact does not decrease the need to investigate the anthropometrical characteristics and body composition numbers of soccer and basketball players, as adequate body composition and body mass figures, among other factors, contribute to optimal exercise routines and performance (Massuça \& Fragoso, 2011). According to these two authors, body mass can influence an athlete's speed, endurance, and power, whereas body composition can affect strength and agility. In other words, successful participation in both soccer and basketball games, next to the high level of technical and tactical skills, also requires from each athlete suitable anthropometrical characteristics and body composition. Most of the descriptive data concerning characteristics of soccer and handball players come from America and Western Europe, although there is a lack of data from Eastern Europe. This study aims to check if this is true for Western Balkan countries. Hence, many previous studies have evaluated ideal anthropometric profiles of successful soccer player (Milanovic et al., 2012; Reilly et al., 2000; Veale, 2010; and others) as well as basketball player (Gualdi-Russo \& Zaccagni, 2001; Bayios et al., 2006; Hooper, 1997; and others) that provide insight into the requirements for competing in the zenith of their particular sports.

Indeed, soccer is a team sport that is played in an outdoor field and requires a high standard of preparation through the development of physical performance skills, as well as tactical and technical expertise, in order to complete for 90 minutes of competitive play. According to Triki and his collaborators, soccer training is mainly based on movement implementing the endurance qualities consisting of moderate activity alternating with periods of intermittent high intensity, leading to a significant production of metabolic heat, mostly due to the reason that the average work intensity during a soccer match is usually about 75 $90 \%$ of maximum heart rate, respectively $70-85 \%$ of $\mathrm{VO}_{2} \max$ (Rexhepi \& Brestovci, 2010b). On the other hand, basketball is also a team sport that is generally played in an indoor field that is much smaller than that of a soccer field, and it requires a high standard of preparation in order to complete for 40 minutes of competitive play and to achieve success. In this game, movement patterns significantly differ from soccer, as it requires intermittent movements and changes continuously in response to different offensive and defensive situations, the average work intensity of a basketball game is above $85 \%$ of maximal heart rate and above $80 \%$ of $\mathrm{VO}_{2} \max$ (Balciunas, 2006; Nudri et al., 1996; Reilly $\&$ Williams, 2005). More running, jumping, and extending are also required.

Hence, the purpose of this study was to describe anthropometric characteristics and body composition profiles of elite soccer and basketball players and to detect possible differences in relation to competition level.

\section{MATERIAL AND METHOD}

Seventy-one males were enrolled in the study. They were divided into three groups: twenty-six soccer players $(23.23 \pm 3.35 \mathrm{yrs})$ from the soccer premier league in Serbia, fourteen basketball players (23.50 $\pm 2.77 \mathrm{yrs})$ from the basketball premier league in Serbia and thirty-one healthy sedentary subjects from the same country $(24.94 \pm 0.54 \mathrm{yrs})$. The measurements were carried out in the first three months of 2007.

All subjects were clinically healthy and had no recent history of infectious disease, asthma or cardio-respiratory disorders. All of them gave their written consent and the local ethics committee approved the protocol of the study. All subjects were assessed for the anthropometric measures required for the calculation of body composition variables, using the standardized procedure recommended by the International Biological Program (IBP) standards respecting the basic rules and principles related to the parameter choice, standard conditions and measurement techniques, as well as the standard measuring instruments adjusted before measurement was carried out. Height and weight were measured in the laboratory with the subject dressed in light clothing. Height was measured to the nearest $0.1 \mathrm{~cm}$ using a fixed stadiometer, and weight was measured to the nearest $0.1 \mathrm{~kg}$ with a standard scale utilizing a portable balance. Body mass index (BMI) was calculated as body mass in kilograms divided by height in meters squared $\left(\mathrm{kg} / \mathrm{m}^{2}\right)$. Skinfolds $(\mathrm{mm})$ were measured at six sites: triceps skinfold thickness, forearm skinfold thickness, thigh skinfold thickness, calf skinfold thickness, chest skinfold thickness and abdominal skinfold thickness (using a skinfold caliper). Each individual measurement and the sum of the six measurements was used for analysis. The circumferences of the upper and lower arm and the upper and lower leg were measured in centimeters and the following diameters were measured to the nearest $0.1 \mathrm{~cm}$ : elbow diameter, wrist diameter, knee diameter, ankle diameter, upper arm diameter, 
forearm diameter, thigh diameter, and calf diameter. To reduce measurement variation, the same investigator examined all of the subjects.

The data obtained in the research was processed using the application statistics program SPSS 10.0, adjusted for use on personal computers. The descriptive statistics were expressed as a mean (SD) for each variable. Analysis of the variance (ANOVA) and the LSD Post Hoc test were carried out to detect the effects for each type of sport (soccer or basketball) on each variable: body height, body weight, body mass index (BMI), and muscle, bone and fat content of the body, as well as to control it by sedentary subjects. The significance was set at an alpha level of 0.05 .

\section{RESULTS}

The anthropometric characteristics of subjects are shown in Table I. There was no significant difference in body mass index among the groups, while a significant difference was found for body height $(\mathrm{F}=29.53)$, body weight $(\mathrm{F}=12.38)$ and all contents of body among the groups: muscle $(\mathrm{F}=5.46)$, bone $(\mathrm{F}=6.75)$ and fat $(\mathrm{F}=35.64)$.

The significant differences of anthropometric characteristics among particular sports are shown in Figure 1. The LSD Post Hoc test indicates that basketball players were significantly taller than soccer players and the subjects of control group, while there was no significant difference between the height of soccer players and the height of the subjects in the control group. This test also indicates that basketball players were significantly heavier than soccer players and the subjects of control group, while there was also significant difference between the weight of soccer players and the subjects of the control group, who were significantly heavier. The muscle and bone contents of the bodies of the subjects in control group were significantly lower than that of all of the other subjects, while there was not any difference between soccer and basketball players. Lastly, the fat content in the bodies of the subjects in the control group was significantly higher than that of all other subjects, while there was no difference between soccer and basketball players.

\section{DISCUSSION}

The results support previous investigations indicating a strong difference regarding the body height among the soccer and basketball players. Thus, selection criteria, different type of play and game rules between the soccer and basketball game can explain the observed difference. However, there has been a tendency to recruit taller and heavier soccer players (cited in Gil et al. 2010), and the absence of the differences between soccer players and subjects of the control group in this study raise doubt the selection process has been carried out correctly, especially due to the fact that soccer players are shorter than the subjects from the control group that represent the general population. Nevertheless, it has to be considered that the average height of all the participants in the 2002 World Soccer Championship was $180.90 \mathrm{~cm}$, while the average height of all players from Czech league $(183.29 \mathrm{~cm})$, Germany $(183.2 \mathrm{~cm})$, Denmark $(183 \mathrm{~cm})$ etc. was higher. This official statistical data proved that soccer players are tall enough and that the doubt may be quenched through investigating the high score of the general population. The tendency to recruit taller soccer players is not unsworn in the scientific literature yet, however, FC Barcelona, which is the shortest team in Europe with only $177.38 \mathrm{~cm}$, has won acclaim around the world with a starting line-up featuring: Victor Valdes (183 cm), Daniel Alves (173 $\mathrm{cm})$, Javier Mascherano $(171 \mathrm{~cm})$, Carles Puyol $(178 \mathrm{~cm})$, Sergio Busquets $(189 \mathrm{~cm})$, Harvey $(168 \mathrm{~cm})$, Cesc Fàbregas $(175 \mathrm{~cm})$, Andrés Iniesta $(170 \mathrm{~cm})$, Lionel Messi $(169 \mathrm{~cm})$, Pedro $(169 \mathrm{~cm})$ and Isaac Cuenca $(181 \mathrm{~cm})$, raising doubts about the veracity of these claims (2010 FIFA World Cup, 2010; FCBarcelona, 2012). On the other hand, basketball players tend to be tall athletes because their players handling a ball above their heads (cited in Gaurav et al., 2010) and because their height helps them to reach toward the basket or toward the top of the net, as well as to defend the ball against opponents. Taller players in basketball have an advantage

Table I. Descriptive data and ANOVA.

\begin{tabular}{lcccc}
\hline \multirow{2}{*}{ Variables } & Soccer $(\mathrm{N}=26)$ & $\begin{array}{c}\text { Basketball } \\
(\mathrm{N}=14)\end{array}$ & Control $(\mathrm{N}=31)$ & ANOVA \\
\cline { 2 - 4 } & Mean \pm Standard Deviation & \\
\hline Height $(\mathrm{cm})$ & $182.11 \pm 6.73$ & $199.50 \pm 7.37$ & $183.72 \pm 7.60$ & $0.000^{*}$ \\
Weight $(\mathrm{kg})$ & $80.10 \pm 7.13$ & $99.57 \pm 11.60$ & $86.74 \pm 14.68$ & $0.000^{*}$ \\
BMI $\left(\mathrm{kg} / \mathrm{m}^{2}\right)$ & $24.11 \pm 1.14$ & $24.94 \pm 1.40$ & $25.61 \pm 3.49$ & $0.086^{\wedge}$ \\
Muscle content of body (\%) & $49.90 \pm 2.78$ & $51.26 \pm 1.99$ & $48.32 \pm 3.27$ & $0.006^{*}$ \\
Bone content of body (\%) & $15.77 \pm 0.92$ & $16.22 \pm 0.77$ & $14.78 \pm 1.78$ & $0.002^{*}$ \\
Fat content of body (\%) & $9.64 \pm 1.60$ & $11.54 \pm 1.97$ & $18.51 \pm 5.89$ & $0.000^{*}$ \\
\hline Legend: $\mathrm{N}$ - number of subjects; BMI - body mass index; ${ }^{\wedge}$ - non-signific ant; * - sig nific ant difference between groups.
\end{tabular}



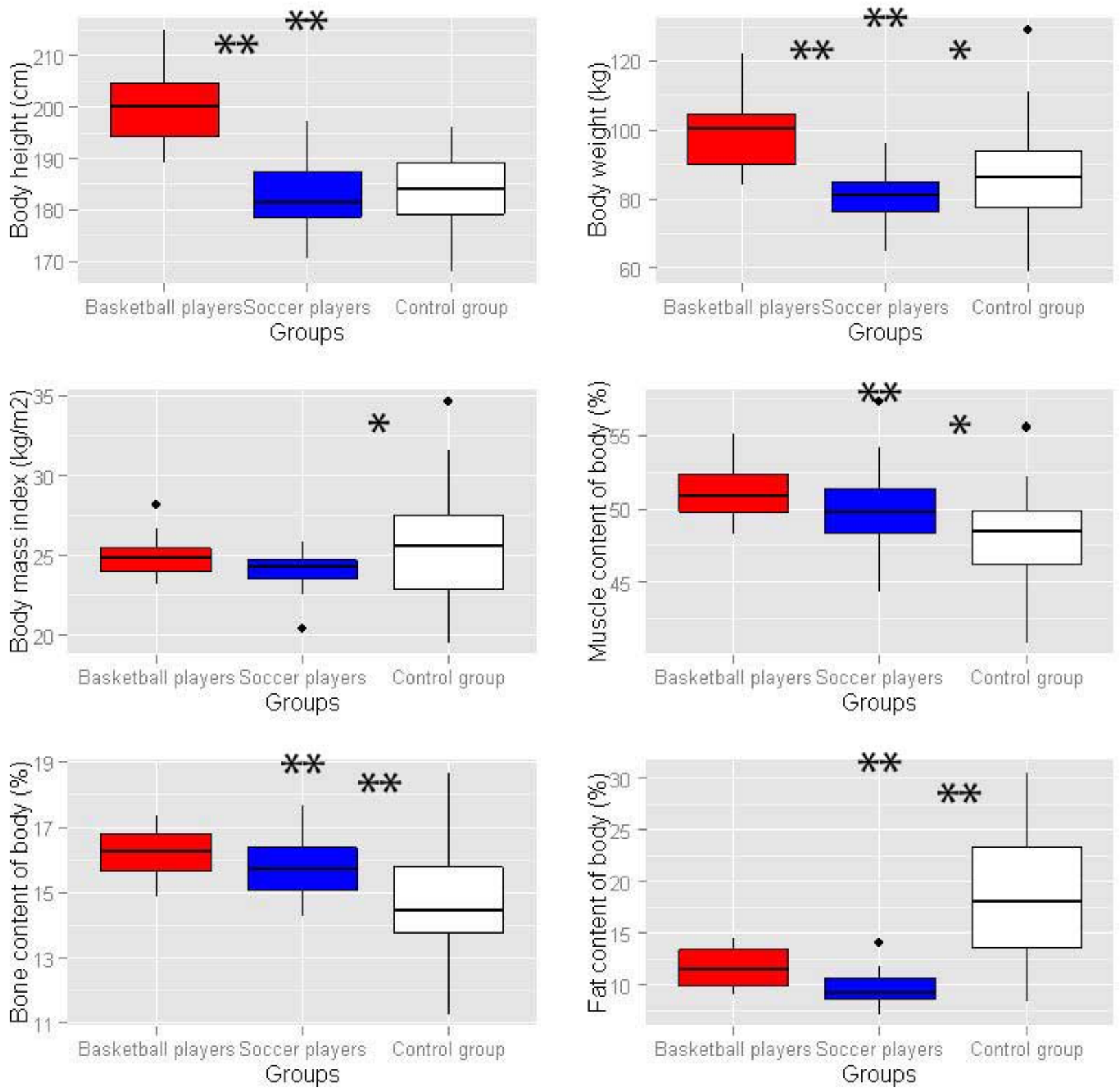

Fig. 1. LSD Post Hoc test. Legend: $* *$ - significance $\leq 0.01, *$ - significance $\leq 0.05$

because their height enables their shot to travel a shorter distance, they start out closer to rebounds, and their ability to jump higher than their opponents gives them a chance to block their shots. For example, the average height of professional basketball players in 2007 to 2008 season, according to available data from NBA.com, was $200.6 \mathrm{~cm}$. From the other side the average heights of the national basketball team's participants in the 2008 Olympic Games in Beijing, according to available data from official website, were following USA $(199.4 \mathrm{~cm})$, Spain $(199.2 \mathrm{~cm})$, Argentina $(199.6 \mathrm{~cm})$ and Lithuania $(201.7 \mathrm{~cm})$. This proves that the players from our basketball premier league are tall enough and they do not lag behind the top players in the world. However, this is not a surprise, as it is well known that the density of very tall subjects appears to be characteristic of the people from this area, since $28 \%$ of people from the general population were measured $190 \mathrm{~cm}$ or above in body height (cited in Bjelica et al., 2012; Popovic et al., 2013). Therefore, this fact may give coaches from Dinaric Alps better working knowledge of this particular group of athletes and suggest to them to follow recent selection process methods and to be more careful during the recruitment, as they have a very tall population in general (Pineu et al., 2005) which confirms the high score of the subjects from control group $(183.72 \mathrm{~cm})$. Furthermore, it was 
expected that basketball players were heavier than soccer players and the subjects of the control group, mostly due to the reason they are significantly taller than both mentioned groups. However, the reason we have such heavier players in basketball has also to do with the fact that the average size of the basketball players has increased dramatically in the past 20-30 years. This could be a function of better nutrition, especially in professional basketball leagues, partly due to the use of nutritional supplements as well as anabolic steroids etc. On the other hand, the body mass index (BMI; weight/height ${ }^{2}$ ) is parameter that is widely used in adult populations such as an internationally recognised definition of overweight and obesity (cited in Kovac et al., 2012). Fortunately, the body mass index of all three groups is in the area of normal weight according to the established literature and it did not show any significant differences among the groups.

Indeed, the authors found that the muscle content of soccer and basketball players was not significantly different (basketball players have a slightly higher percentage of muscle content); however, both groups of athletes showed significantly higher percent of muscle content than control subjects. The same case was found regarding the bone content profiles measured in this study. These results may be explained by more demands to grow the muscle contents of the body in sportsmen, while a slightly higher percentage of muscle content of basketball players was found as this game requires intermittent activities when high-intensity activities are followed by low-intensity type of movements. It is also interesting to mention that basketball players have to use both upper and lower extremities, while soccer players use just lower extremities, possibly an additional reason why the authors reach these results. Furthermore, it was expected that soccer players would have a higher percent of bone mass at the expense of muscle mass, mostly due to the fact that this case came from the comparative study of body composition that is conducted between elite soccer and handball players (Popovic et al., 2012); however, this wasn't the case and basketball players had a higher percent of bone mass. Moreover, it was expected that the percent of fat mass of the control group would be significantly higher than the soccer and basketball players and these results could be explained by less physical activity in the controls. However, it is interesting to note that the percent of fat content in the bodies of basketba11 players was insignificantly higher than the percent of fat content in the bodies of soccer players. These results were not expected, mostly due to the reason that much of the previous research recognized soccer as a predominantly aerobic sport (Kemi et al., 2003; Stolen et al., 2005), while anaerobic energy is essential only to performance in sprints, high-intensity runs, and duel plays, all of which may contribute to the final outcome of the game (cited in Sporis et al., 2008). Whereas, basketball training contains more anaerobic activity (20\% to $25 \%$ aerobic activity and $75 \%$ to $80 \%$ anaerobic activity) than soccer (Brittenham, 1996) as this game is intermittent and changes continuously in response to different offensive and defensive situations and demands more anaerobic exercises that are high-intensity exercises done at a short and explosive burst. These results were not expected, also due to the reason that basketball matches have a duration of 40 minutes divided in four quarters lasting 10 minutes each, while soccer matches have a duration of 90 minutes divided into two halves lasting 45 minutes each and, through the matches, basketball player cover a total distance ranging approximately from 5,000 to 7,000 meters (Dezman \& Erculj, 2005; Erculj \& Supej, 2006), while soccer players cover a total distance ranging approximately from 10,000 to 12,000 meters (Dellal et al., 2010). These distances are based upon different circumstances in each sport, the first of all it depends on position, then tactical defensive or offensive characteristics, or general characteristics of the game.

The importance of body composition in sport performance is a primary concern in creating athlete profiles as well as conditioning programs throughout a season at all levels of competition (Silvestre et al., 2006), mostly due to the reason that describing anthropometric characteristics and body compositions of athletes and detecting possible differences in relation to competition levels may give coaches a better working knowledge of the studied groups of athletes. Moreover, the results of this study suggest that soccer and basketball increased the percent of muscle content (using the comparison of the control group, which participants had a higher percentage of body fat). On the other hand, this study also suggests that the bone content of both athletes groups seems to be explained as a greater percent compared to the subjects of the control group, while the differences in the body weight is logical consequence. Lastly, the part attributed to the body height is the main causes of selection process. Hence, an increased focus on these variables is essential.

Considering that the measurements were conducted in the middle of the season, this study is limited by the fact that changes in body composition and physical performance may occur from the start to the end of an athlete's training and competitive season (cited in Silvestre et al., 2006). Kraemer et al. (2004), reported that soccer players who enter a season with a high catabolic metabolic status could experience reductions in performance during a competitive season accompanied by detrimental changes in body composition. Accordingly, further studies should be very careful in projecting timelines for measuring anthropometric characteristics and body composition, mostly due to the fact that it has to be conducted either at the beginning or at the end of a season. It also has to be explicitly reported when the measurement was conducted. 
POPOVIC, S.; AKPINAR, S.; JAKSIC, D.; MATIC, R. \& BJELICA, D. Estudio comparativo de las medidasantropométricas y composición corporal entre futbolistas de elite y jugadores de básquetbol. Int. J. Morphol., 31(2):461-467, 2013.

RESUMEN: El propósito de este estudio fue describir las características antropométricas y de composición corporal de los jugadores de fútbol y básquetbol de élite, así como hacer comparaciones entre ellos. Setenta y un hombres fueron incluidos en el estudio, divididos en tres grupos: 26 jugadores de fútbol, 14 jugadores de básquetbol y 31 sujetos sedentarios sanos. Todos los sujetos fueron evaluados para obtener las medidas antropométricas requeridas para el cálculo de las variables de composición corporal, utilizando los procedimientos normalizados recomendados. Los datos fueron analizados mediante el programa SPSS y los datos estadísticos descriptivos se expresaron como media (desviación estándar) para cada variable. Además se utilizaron las pruebas de ANOVA y LSD que se llevaron a cabo para detectar los efectos de cada tipo de deporte. Los resultados mostraron que no existía diferencia significativa en el índice de masa corporal entre los grupos, mientras que se encontró una diferencia estadísticamente significativa para la altura del cuerpo y el peso corporal, así como para las tres variables medidas del cuerpo (músculo, hueso y grasa) entre los grupos. Los jugadores de básquetbol fueron significativamente más altos y pesados que los jugadores de fútbol y los sujetos del grupo de control, mientras que también hubo una diferencia significativa entre el peso de los jugadores de fútbol y los sujetos del grupo de control, que fueron significativamente más pesados. El contenido muscular y óseo de los sujetos en el grupo control fue significativamente menor, mientras que no hubo diferencias entre los jugadores de fútbol y baloncesto. Por último, el contenido de grasa en el cuerpo de los sujetos en el grupo de control fue significativamente mayor que la de los otros sujetos, mientras que no hubo diferencia entre los jugadores de fútbol y de básquetbol. Por lo tanto, estos hallazgos pueden dar a los entrenadores de la región un mejor conocimiento y sugerir a ellos seguir los últimos métodos de proceso de selección y ser más cuidadoso durante el reclutamiento.

PALABRAS CLAVE: Deporte de elite; Fútbol; Básquetbol, Hombres.

\section{REFERENCES}

2010 FIFA World Cup. 2010 FIFA World Cup South Africa Players, 2010. Retrieved on July 25, 2012, from http:// www.fifa.com/worldcup/archive/southafrica2010/players/ index.html/.

Balciunas, M.; Stonkus, S.; Abrantes, C. \& Sampaio, J.. Long term effects of different training modalities on power, speed, skill and anaerobic capacity in young male basketball players. Journal of Sports Science and Medicine, 5(2):163-70, 2006.

Bayios, I.A.; Bergeles, N.K.; Apostolidis, N.G.; Noutsos, K.S. \& Koskolou, M.D. Anthropometric, body composition and somatotype differences of Greek elite female basketball, volleyball and handball players. Journal of Sports Medicine and Physical Fitness, 46(2):271-80, 2006.

Bjelica, D.; Popovic, S.; Kezunovic, M.; Petkovic, J.; Jurak, G. \& Grasgruber, P. Body Height and Its Estimation Utilizing Arm Span Measurements in Montenegrin Adults. Anthropological Notebooks, 18(2):69-83, 2012.

Brittenham, G. Complete Conditioning for Basketball. New York: Human Kinetics, 1996.

Carvajal, W.; Betancourt, H.; León, S.; Deturnel, Y.; Martínez, M.; Echevarría, I.; Eugenia Castillo, M. \& Serviat, N. Kinanthropometric Profile of Cuban Women Olympic Volleyball Champions. MEDICC Review, 14(2):16-22, 2012.

Dellal, A.; Wong, D.P.; Moalla, W. \& Chamari, K. Physical and technical activity of soccer players in the French First League - with special reference to their playing position. International SportMed Journal, 11(2):278-90, 2010.
Dezman, B. \& Erculj, F. Conditioning for Basketball (In Slovene). Ljubljana: Faculty of Sport, Institute of Sport, 2005.

Erculj, F. \& Supej, M. The Impact of Fatigue on Jump Shot Height and Accuracy over a Longer Shooting Distance in Basketball. Ugdymas. Kûno Kultûra. Sportas, 63(4):35-41, 2006.

FCBarcelona, 2012. The official FC Barcelona website, 2012. Retrieved on July 25, 2012, from http://arxiu.fcbarcelona.cat/ web/english/.

Gaurav, V.; Singh, M. \& Singh, S. Anthropometric characteristics, somatotyping and body composition of volleyball and basketball players. Journal of Physical Education and Sports Management, 1(3):28-32, 2010.

Gil S.M.; Gil J.; Ruiz F.; Irazusta A. \& Irazusta J. Anthropometrical Characteristics and Somatotype of Young Soccer Players and Their Comparison with the General Population. Biology of Sport, 27(1):17-24, 2010.

Gualdi-Russo, E. \& Zaccagni, L. Somatotype, role and performance in elite volleyball players. Journal of Sports Medicine and Physical Fitness, 41(2):256-62, 2001.

Hadzic, R.; Bjelica, D. \& Popovic, S. Comparative study of anthropometric measurement and body composition between elite basketball and volleyball players. Research in physical education, sport and health, 1(1):103-8, 2012.

Hooper, D. M. Somatotype in high performance female netball players may influence player position and the incidence of lower limb and back injuries. British Journal of Sports Medicine, 31(3):197-9, 1997. 
Kemi, O. J.; Hoff, J.; Engen, L.C. \& Wisloff, U. Soccer specific testing of maximal oxygen uptake. The Journal of Sports Medicine and Physical Fitness, 43(2):139-44, 2003.

Kovac, M.; Jurak, G. \& Leskosek, B. The prevalence of excess weight and obesity in Slovenian children and adolescents from 1991 to 2011. Anthropological Notebooks, 18(1):91-103, 2012.

Kraemer, W.J.; French, D.N.; Paxton, N.J.; Häkkinen, K.; Volek, J.S.; Sebastianelli, W.J.; Putukian, M.; Newton, R.U.; Rubin, M.R.; Gómez, A.L.; Vescovi, J.D.; Ratamess, N.A.; Fleck, S.J.; Lynch, J.M. \& Knuttgen, H.G. Changes in exercise performance and hormonal concentrations over a Big Ten soccer season in starters and nonstarters. The Journal of Strength \& Conditioning Research, 18(1):121-8, 2004.

Massuça, L. \& Fragoso, I. Study of Portuguese handball players of different playing status. A morphological and biosocial perspective. Biology of Sport, 28(1):37-44, 2011.

Milanovic, D.; Vuleta, D. \& Sisic, A. Comparative Analysis of Morphological Characteristics of Goalkeepers in Football and Handball. Montenegrin Journal of Sports Science and Medicine, 1(1): 5-9, 2012.

Nudri, W. D.; Ismail, M. N. \& Zawiak, H. Anthropometric measurements and body composition of selected national athletes. Malaysian Journal of Nutrition, 2:138-47, 1996.

Pineau, J.C.; Delamarche, P. \& Boz`inovic’', S. Average height of adolescents in the Dinaric Alps (in French). Comptes Rendus Biologies, 328(9):841-6, 2005.

Popovic, S.; Bjelica, D.; Petkovic, J. \& Muratovic, A. Comparative Study of Anthropometric Measurement and Body Composition between Elite Soccer and Handball Players. In: $4^{\text {th }}$ International Scientific Conference "Contemporary Kinesiology”. Split: Faculty of Kinesiology, University of Split, 2012. pp.102-8.

Popovic, S.; Bjelica, D.; Molnar, S.; Jaksic, D. \& Akpinar, S. Body Height and Its Estimation Utilizing Arm Span Measurements in Serbian Adults. Int. J. Morphol., 31(1):271-9, 2013.

Reilly, T.; Bangsbo, J. Franks, A. Anthropometric and physiological predispositions for elite soccer. Journal of sports sciences, 18(9):669-83, 2000

Reilly, T. \& Williams, M. A. Science and soccer. New York, Routledge, 2005.

Rexhepi, A. \& Brestovci, B. Differences in bodily growth between young footballers and basketball players. Int. J. Morphol., 28(2):415-20, 2010a.

Rexhepi, A. \& Brestovci, B. The differences in body volume and skinfold thickness between basketball players and footballers. Int. J. Morphol., 28(4):1068-74, 2010 b.
Silvestre, R.; Kraemer, W.J.; West, C.; Judelson, D.A.; Spiering, B.A.; Vingren, J.L.; Hatfield, D.L.; Anderson, J.M. \& Maresh, C.M. Body Composition and Physical Performance during a National Collegiate Athletic Association Division I Men's Soccer Season. J. Strength and Conditioning Research, 20(4): 962-70, 2006.

Singh, S.; Singh, K. \& Singh, M. Anthropometric measurements, body composition and somatotyping of high jumpers. Brazilian Journal of Biomotricity, 4(4):266-71, 2010.

Sporis, G.; Ruzic, L. \& Leko, G. The Anaerobic Endurance of Elite Soccer Players Improved After a High-Intensity Training Intervention in the 8-Week Conditioning Program. Journal of Strength and Conditioning Research, 22(2):559-66, 2008.

Stolen, T.; Chamari, K.; Castagna, C. \& Wisloff, U. Physiology of soccer: an update. Sports Medicine, 35(6): 501-36, 2005.

Strudwick, A.; Reilly, T. \& Doran, D. Anthropometric and fitness profiles of elite players in two football codes. Journal of sports medicine and physical fitness, 42(2):239-42, 2002.

Triki, M.; Rebai, H.; Abroug, T.; Masmoudi, K.; Fellmann, N.; Zouari, M. \& Tabka, Z. Comparative study of body composition and anaerobic performance between football and judo groups. Science and Sports, 27(5):293-9, 2012.

Veale, J. P.; Pearce, A. J.; Buttifant, D. \& Carlson, J.S. Anthropometric profiling of elite junior and senior Australian football players. International journal of sports physiology and performance, 5(4):509-20, 2010.

Wilmore, J. H. Body composition and athletic performance. In W. Haskell; J. Scala \& J. Whittam (Eds.), Nutrition and Athletic Performance. California, USA, Bull Publishing, 1982. pp. 15875.

\section{Correspondence to:}

Stepo Popovic

Faculty for Sport and Physical Education

University of Montenegro

Narodne omladine bb,

81400 Niksic

MONTENEGRO

Tel: $00382(40) 235207$

Fax: 00382 (40) 2352000

E-mail: stevop@ac.me

Received: 28-09-2012

Accepted: 11-02-2013 